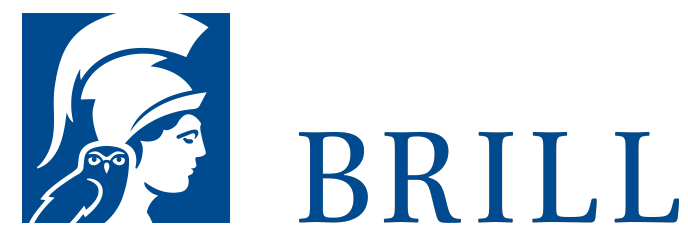

\title{
Ökonomische Theorie des Gesellschaftsvertrags
}

James Buchanans Konstitutionelle Politische Ökonomie

Author: Dirk Brantl

Seit den 1970er Jahren ist die Theorie des Gesellschaftsvertrags wieder zur dominanten Begründungsstrategie politischer Legitimität geworden. Im Rahmen dieser Entwicklung haben ökonomische Elemente wie die Entscheidungs- und die Spieltheorie, aber auch der ökonomische Rationalitätsbegriff Eingang in die Politische Philosophie gefunden. Zeitgleich findet innerhalb der Wirtschaftswissenschaften der Versuch statt, die Anwendung ökonomischer Methoden auf nichtwirtschaftliche Zusammenhänge auszuweiten. Diese beiden Entwicklungen kreuzen sich im Versuch verschiedener Denker, die Theorie des Gesellschaftsvertrags in ihrer Breite ökonomisch zu rekonstruieren. Das Buch will am Beispiel des umfassendsten Versuchs, diesen so genannten "ökonomischen Ansatz" für die Vertragstheorie fruchtbar zu machen, James Buchanans Entwurf einer Konstitutionellen Politischen Ökonomie, Stärken und Grenzen desselben ausloten. Entgegen der gängigen Praxis wird dabei versucht, den methodischen Ansatz der Ökonomie nicht eo ipso mit einer unerlaubten Ökonomisierung, einem Ökonomismus, gleichzusetzen, sondern vielmehr den Versuch einer methodischen Innovation vorurteilsfrei zu evaluieren.

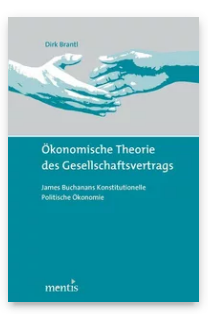

Pages: 248

Seiten

Language:

German

Subjects:

General,

Philosophy

Publisher: Brill | mentis

E-Book (PDF)

Released online:

O1 Feb 2013

ISBN: 978-3-

95743-96o-4

List price

Paperback

Publication date: o1 Feb 2013

ISBN: 978-389785-786-5

List price 
For more information see brill.com

Order information: Order online at brill.com +44330 333 0049 | customerservices@brill.com Submission information: brill.com/authors

Titles published by Brill | Fink, Brill | mentis or Brill | Schöningh: +49(o)715413279216| brill@brocom.de 